Historic, Archive Document

Do not assume content reflects current scientific knowledge, policies, or practices. 



\section{Can I Serid You Some Free Seed Corn Samples?}

I want you to see some of of our seed corn. I diid think of sencling some samples along with the catalng, tut l didn't know whether you woud core fur teem or not, and I didn't know what kind, would suit you best anyway, so I thought 1 better wait and hear from you first.

We've got the golods all right, and we are not afraid to stow thiem up. You can tell that when you see the sair ples.

Mark the kinds you are interested in and would like to see, You are vielcome to them whether you interid to order cr not.

Shenandoah Yellow.... Cornplanter..........

White Elephant...... Icwa Silvermine.......

Ried's Yellow I)ent... Pride of the North ....

Boone County White. Red 90 day...........

Shenandoah Srpecial... Ensilage Corn......... them.

Don't be bepshful. We are anxious to send How many acres will you have this year?...... Which do you iprefer, white..... or yellow.......corn?

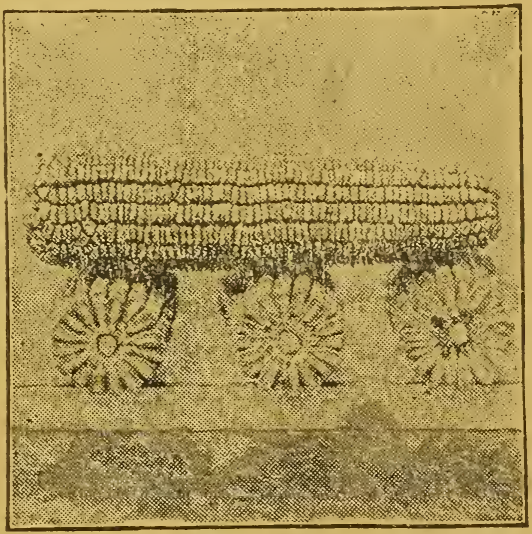

Write address on other side. 


\section{POSt}

Carsd

Please send me the Free Samples of seed corn marked on other side of this card.

Name

P. O...

State
Henry Field Seed Co..

Shenaindoah,

Iowa. 